\title{
Pengaruh Faktor Internal Perusahaan terhadap Kebijakan Dividen Pada Perusahaan LQ45
}

\author{
Mita Handayani*, Anita Wijayanti, Suhendro \\ Universitas Islam Batik Surakarta, Jl. KH. Agus Salim No. 10, Jawa Tengah, Indonesia \\ *Correspondence e-mail: handayanimita205@gmail.com
}

\begin{abstract}
Abstrak. Mengharapkan pendapatan atau adanya pengembalian investasi (return) dari perusahaan yaitu target umum investor dalam berinvestasi. Dividen adalah salah satu pendapatan yang diinginkan investor. Penelitian ini bertujuan untuk menganalis is pengaruh profitabilitas, likuiditas, ukuran perusahaan, sales growth dan IOS terhadap kebijakan dividen. Untuk penelitian ini diambil pada perusahaan LQ45 yang terdaftar di Bursa Efek Indonesia periode 2015 sampai 2019. Melalui purposive sampling terpilih 18 perusahaan yang memenuhi kriteria penelitian, sehingga sampel adalah 90 observasi. Metode pengujian data melalui regresi linier berganda. Hasil penelitian berdasarkan uji $\mathrm{F}$ menunjukkan semua variabel independen dalam penelitian berpengaruh secara simultan terhadap kebijakan dividen, sedangkan berdasarkan uji t menghasilkan profitabilitas, ukuran perusahaan dan IOS tidak berpengaruh terhadap kebijakan dividen, namun likuiditas berpengaruh terhadap kebijakan dividen serta sales growth berpengaruh negatif terhadap kebijakan dividen.
\end{abstract}

Kata kunci: Likuiditas; Sales Growth; Kebijakan Dividen

Abstract. Expecting income or return from the company is the general target of investors in investing. Dividends are one of the incomes that investors want. This study aims to analyze the influence of profitability, liquidity, company size, sales growth and IOS on dividend policy. For this research was taken in LQ45 companies listed on the Indonesia Stock Exchange for the period 2015 to 2019. Through purposive sampling selected 18 companies that meet the research criteria, so that the sample is 90 observations. Data testing method through multiple linear regression. The results of the study based on the F test showed that all independent variables in the study had a simultaneous effect on dividend payout ratio, while based on t-test resulting in profitability, company size and IOS had no effect on dividend payout ratio, but liquidity had an effect on dividend payout ratio and sales growth negatively affected dividend payout ratio.

Keywords: Liquidity; Sales Growth; Dividend Payout Ratio

\section{PENDAHULUAN}

Investasi adalah kegiatan menanamkan modalnya dengan tujuan memperoleh return dimasa mendatang. Dalam menanamkan sejumlah modal atau dana tersebut akan dihadapkan dua unsur yaitu hasil dan risiko yang sulit diprediksi oleh para investor. Karena itu untuk meminimalisir risiko terkait saat melakukan investasi, investor memerlukan informasi berupa financial performance yang tercermin pada laporan keuangan perusahaan yang dijadikan objek investasi guna melihat prospek perkembangan dan kondisi keuangan perusahaan dimasa mendatang. Manajemen perusahaan mengalokasikan pendapatannya dalam bentuk dividen akan memberikan peluang bagi investor bahwa perusahaan tercatat akan menunjukkan laba perusahaan meningkat dimasa mendatang (Hesniati and Hendra, 2019).

Dalam berinvestasi diperusahaan pun sering terjadi muncul permasalahan berkaitan dengan kebijakan dividen, yaitu kebijakan penentuan pembagian laba yang didapat perusahaan akhir tahun antara untuk dibayarkan sebagai bentuk dividen kepada pemegang saham atau ditahan untuk meningkatkan modal guna pendanaan investasi di masa depan (Riyanto, 2011). Kebijakan dividen perusahaan tercermin dari dividend payout ratio yaitu berapa besar EAT yang didistribusikan sebagai dividen pada pemegang saham. Makin besar laba yang didistribusikan bentuk dividen, akan menguntungkan pihak pemegang saham tapi akan berdampak lemahnya dana internal perusahaan karena memperkecil jumlah laba ditahan yang dialokasikan. Sebaliknya menurut Putri \& Andayani (2017) jika pembagian laba dalam bentuk dividen rendah akan mengecewakan pihak pemegang saham tapi menguatkan dana internal perusahaan.

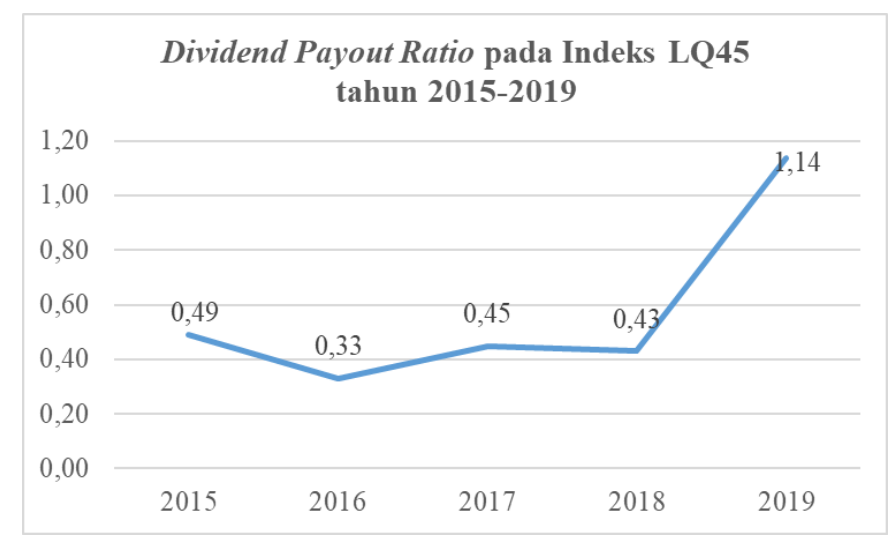

Gambar 1. Perbandingan DPR periode 2015-2019

Berdasarkan grafik yang tersaji diatas menggambarkan kondisi rata-rata DPR di perusahaan 
LQ45 periode 2015 sampai 2019 mengalami fluktuatif setiap tahunnya. Pada periode tahun 2016 mengalami penurunan sebesar 0,33. Tahun 2017 terjadi peningkatan siginifikan yang bisa terlihat jelas sebesar 0,45 . Kemudian 2018 terjadi penurunan tipis 0,43 dan tahun 2019 terjadi peningkatan kembali 1,14. Hal tersebut berarti terdapat faktor yang dapat mempengaruhi penentuan kenaikan dan penurunan DPR. Salah satunya pertimbangan faktor internal mengenai bagaimana kondisi keuangan perusahaan dan skala prioritas investasi dilakukan (Noor, 2009).

Profitabilitas merupakan pertimbangan direksi secara langsung dapat mempengaruhi penentuan kebijakan dividen. Semakin tinggi profitabilitas akan membuat semakin besar perusahaan mampu membagikan dividen, hal ini karena berpengaruhnya ketersediaan anggaran yang diperoleh dari laba untuk dialokasikan sebagai dividen, (Sartono, 2010). Penelitian Kurniawan \& Jin (2017) menunjukkan profitabilitas berpengaruh positif terhadap kebijakan dividen, sejalan dengan Ali et al (2018) dan Hesniati \& Hendra (2019). Namun kontradiktif dengan Sejati et al (2020) dan Lin et al (2018) menyatakan profitabilitas tidak berpengaruh terhadap kebijakan dividen.

Posisi likuiditas perusahaan juga sangatlah mempengaruhi pada kemampuan dividen yang akan dibayarkan, karena dividen dibayar secara tunai tidak dengan laba ditahan, maka makin baik posisi likuiditas perusahaan makin baik pula kesanggupannya untuk membayar dividen (Sutrisno, 2013). Penelitian Kurniawan \& Jin (2017), dan Ahmad et al (2019) menunjukkan likuiditas memiliki pengaruh positif signifikan terhadap kebijakan dividen. Namun kontradiktif dengan Patrick et al (2017), dan Lin et al (2018) bahwa likuiditas tidak berpengaruh terhadap kebijakan dividen.

Mui \& Mustapha (2016) mengemukakan ukuran perusahan dianggap mampu mempengaruhi sebuah perusahaan dalam penentukan kebijakan dividen. Hal ini dibuktikan kemampuan perusahaan ukuran yang relatif lebih besar cenderung memiliki arus kas operasi lebih stabil dibanding perusahaan kecil, maka dari itu makin besar ukuran perusahaan peluang besarnya dividen didistribusikan juga semestinya ikut meningkat. Penelitian Kurniawan \& Jin (2017) dan Hesniati \& Hendra (2019) menunjukkan bahwa ukuran perusahaan memiliki pengaruh positif terhadap kebijakan dividen. Namun kontradiktif dengan Patrick et al (2017), Ahmad et al (2019) dan Hasanuh (2019) menyatakan ukuran perusahaan tidak berpengaruh terhadap kebijakan dividen.

Sales growth menggambarkan perubahan penjualan tahunan dalam bersaing dipasar. Semakin tinggi tingkat sales growth berpengaruh pada laba tinggi yang didapatkan, dengan laba tinggi tersebut akan membuat perusahaan dalam pembagian dividennya akan tinggi pula. Penelitian Hesniati \& Hendra (2019) menunjukkan sales growth berpengaruh negatif terhadap kebijakan dividen. Namun kontradiktif dengan Kurniawan \& Jin (2017) menyatakan sales growth tidak berpengaruh terhadap kebijakan dividen.

Peluang investasi dimasa mendatang menjadi kesempatan yang juga dipertimbangkan suatu perusahaan. Bila perusahaan memiliki peluang investasi yang besar, maka hal tersebut cenderung akan menghasilkan sasaran dividen tunai semakin kecil yang akan dibagikan untuk pemegang saham dan sebaliknya bila perusahaan memperoleh peluang investasi (IOS) dalam jumlah sedikit (Brigham and Houston, 2011). Penelitian Mui \& Mustapha (2016) dan Aini \& Sawitri (2020) menunjukkan IOS berpengaruh terhadap kebijakan dividen. Namun kontradiktif Fadhilaturrochmah \& Subardjo (2017) menyatakan IOS tidak berpengaruh terhadap kebijakan dividen.

Berdasarkan latar belakang yang dijabarkan di atas menggambarkan adanya pebedaan hasil dari peneliti sebelumnya yang tidak konsisten (reseach gap) dan fenomena DPR pada Perusahaan LQ45 periode 20152019. Hal tersebut menyebabkan keterkaitan penulis untuk meneliti lebih lanjut berfokus pada perusahaan LQ45 yang listed di BEI periode 2015-2019.

Dengan menguji pengaruh pada kebijakan dividen, hipotesis dalam penelitian ini antara lain:

H1:Profitabilitas berpengaruh terhadap kebijakan dividen pada perusahaan LQ45

$\mathrm{H} 2$ :Likuiditas berpengaruh terhadap kebijakan dividen pada perusahaan LQ45

H3:Ukuran perusahaan berpengaruh terhadap kebijakan dividen pada perusahaan LQ45

H4:Sales growth berpengaruh terhadap kebijakan dividen pada perusahaan LQ45

H5:IOS berpengaruh terhadap kebijakan dividen pada perusahaan LQ45

\section{METODE}

Metode penelitian ini tergolong pada pendekatan kuantitatif karena melibatkan perhitungan dan menganalisis data bersifat kuantitatif dalam bentuk digital. Populasi yang digunakan oleh penulis yaitu Perusahaan LQ45 yang listed di Bursa Efek Indonesia periode tahun 2015 sampai 2019. Teknik pengambilan sampel menggunakan teknik purposive sampling, yang mana terdapat beberapa kriteria penentuan sampel: (1) Perusahaan konsisten masuk pada indek LQ45 periode 2015-2019; (2) Perusahaan LQ45 menerbitkan laporan keuangan secara berturut dan menyajikan data lengkap memenuhi kriteria dengan periode 31 desember; (3) Perusahaan LQ45 yang menggunakan rupiah sebagai mata uang pelaporan; (4) Perusahaan LQ45 yang membagikan dividen selama tahun 2015-2019.

Sedangkan untuk metode pengujian data melalui analisis regresi linear berganda dengan aplikasi pengolahan data SPSS versi 21. 


\section{Variabel Penelitian dan Pengukurannya}

Variable terikat penelitian ini yaitu kebijakan dividen, sedangkan variable bebas terdapat 5 variasi antara lain yaitu profitabilitas, likuiditas, ukuran perusahaan, sales growth dan IOS.

\section{Pengukuran Kebijakan Dividen}

Kebijakan dividen diproksikan Dividend Payout Ratio, yang mana melalui rasio ini perusahaan dapat mengukur berapa besar tingkat EAT yang didistribusikan bentuk dividen untuk pemegang saham, secara matematis dapat dirumus berikut, (Sudana, 2015):

$$
D P R=\frac{\text { Dividend }}{\text { Earnings After Tax (EAT) }}
$$

\section{Pengukuran Profitabilitas}

Profitabilitas diproksikan return on asset, yang mana melalui rasio ini perusahaan dapat mengetahui tingkat laba yang dihasilkan terhadap jumlah aset keseluruhan. ROA dirumuskan dalam persamaan berikut (Kasmir, 2012):

ROA $=\frac{\text { Laba Bersih Setelah Pajak }}{\text { Total Asset }}$

\section{Pengukuran Likuiditas}

Likuiditas diproksikan dengan current rasio, yang mana melalui rasio ini menunjukkan berapa besar daya perusahaan mampu dalam memenuhi atau membayar kewajiban jangka pendeknya. CR dirumuskan dalam persamaan berikut (Kasmir, 2012):

\section{$\mathrm{CR}=\frac{\text { Aset Lancar }}{\text { Kewajiban Lancar }}$}

\section{Pengukuran Ukuran Perusahaan}

Ukuran perusahaan yaitu banyaknya aset yang dimiliki suatu perusahaan, yang diproksikan Ln (Natural Logaritma) dikalikan dengan total aset, (Sutrisno, 2013):

$$
\text { Size }=\operatorname{Ln}(\text { Total Aset })
$$

\section{Pengukuran Sales Growth}

Sales growth digunakan untuk menggambarkan presentasi dari kenaikan atau penurunan penjualan tahun sekarang dibandingkan dengan tahun sebelumnya. Dapat dirumuskan dalam persamaan berikut (Harahap, 2016):

Sales Growth $=\frac{\text { Penjualan T }- \text { Penjualan } \mathrm{T}-1}{\text { Penjualan } \mathrm{T}-1}$

\section{Pengukuran Investment Opportunity Set (IOS)}

IOS diproksikan dengan MVE/BVE yang diperoleh melalui mengalikan jumlah saham yang beredar dengan closing price terhadap jumlah modal keseluruhan. Pemilihan proksi mengacu pada (Hanafi, 2004):

MVE $/$ BVE $=\frac{\text { (Jumlah saham beredar } x \text { harga penutupan saham) }}{\text { Total Ekuitas }}$

\section{HASIL DAN PEMBAHASAN}

Berdasarkan kriteria penentuan sampel yang sudah dibahas sebelumnya diperoleh sampel dengan rincian tabel 1:

Tabel 1. Kritera Penentuan Sampel

\begin{tabular}{lc}
\hline \multicolumn{3}{c}{ Kriteria Sampel } & Jumlah \\
\hline 1. Perusahaan LQ45 yang terdaftar di Bursa & 45 \\
Efek Indonesia & \\
2. Perusahaan yang tidak konsisten masuk & $(17)$ \\
dalam indeks LQ45 periode 2015-2019 & \\
3. Perusahaan LQ45 tidak menerbitkan & $(6)$ \\
laporan keuangan secara berturut dan & \\
menyajikan data lengkap memenuhi kriteria & \\
4. Perusahaan LQ45 yang tidak menggunakan \\
rupiah sebagai mata uang pelaporan
\end{tabular}

Sumber: Data Diolah Peneliti, 2020

\section{Uji Asumsi Klasik}

Tabel 2. Uji Normalitas

\begin{tabular}{lccc}
\hline & $\begin{array}{c}\text { Unstandardired } \\
\text { Residual }\end{array}$ & Std & Keputusan \\
\hline $\begin{array}{l}\text { Asymp.Sig } \\
\text { (2-tailde) }\end{array}$ & 0,192 & $>0,05$ & $\begin{array}{c}\text { Terdistribusi } \\
\text { normal }\end{array}$ \\
\hline
\end{tabular}

Sumber: Hasil Data Olahan Peneliti, 2020

Tabel 3. Uji Multikolinearitas

\begin{tabular}{lcccl}
\hline Variabel & Tolerance & Std & VIF & Keputusan \\
\hline Profitabilitas & 0,293 & $>0,1$ & 3,416 & Tidak terjadi \\
Likuiditas & 0,695 & $>0,1$ & 1,438 & Tidak terjadi \\
Ukuran & 0,551 & $>0,1$ & 1,814 & Tidak terjadi \\
Perusahaan & & & & \\
Sales Growth & 0,949 & $>0,1$ & 1,053 & Tidak terjadi \\
IOS & 0,344 & $>0.1$ & 2,910 & Tidak terjadi \\
\hline
\end{tabular}

Sumber : Hasil Data Olahan Peneliti, 2020

Tabel 4. Uji Autokolerasi

\begin{tabular}{lccc}
\hline & $\begin{array}{c}\text { Unstandardized } \\
\text { Residual }\end{array}$ & Std & Keterangan \\
\hline $\begin{array}{l}\text { Asymp.Sig } \\
\text { (2-tailed) }\end{array}$ & 0,90 & $>0,95$ & $\begin{array}{c}\text { Tidak ada } \\
\text { autokolerasi }\end{array}$ \\
\hline
\end{tabular}

Sumber: Hasil Data Olahan Peneliti, 2020

Tabel 5. Uji Heteroskedastisitas

\begin{tabular}{lccc}
\hline \multicolumn{1}{c}{ Variabel } & Sig & Std & Keterangan \\
\hline Profitabilitas & 0,484 & $>0,05$ & Bebas heteroskedastisitas \\
Likuiditas & 0,157 & $>0,05$ & Bebas heteroskedastisitas \\
Ukuran & 0,324 & $>0,05$ & Bebas heteroskedastisitas
\end{tabular}


Mita Handayani, Anita Wijayanti dan Suhendro, Pengaruh Faktor Internal Perusahaan terhadap Kebijakan Dividen Pada Perusahaan LQ45

Perusahaan

Sales $\quad 0,424>0,05 \quad$ Bebas heteroskedastisitas

Growth

IOS $\quad 0,190>0,05 \quad$ Bebas heteroskedastisitas

Sumber : Hasil Data Olahan Peneliti, 2020

Berdasarkan seperti tersaji pada tabel 2-5 diatas uji asumsi klasik dilakukan agar uji regresi berganda pada penelitian memiliki hasil yang tidak bias dan signifikan. Dari hasil tersebut yang dilakukan peneliti dapat ditarik simpulan semua model regresi tercantum diatas telah memenuhi kriteria asumsi klasik.

\section{Uji Regresi Linier Berganda}

Tabel 6. Uji Regresi

\begin{tabular}{lc}
\hline Variabel & Unstandardized Coefficients \\
& $\mathrm{B}$ \\
\hline (Constant) & $-0,179$ \\
Profitabilitas & 0,382 \\
Likuiditas & 0,091 \\
Ukuran Perusahaan & 0,030 \\
Sales Growth & $-0,459$ \\
Investment Opportunity Set & 0,007
\end{tabular}

Sumber: Hasil Data Olahan Peneliti, 2020

Berdasarkan tersaji pada tabel 6 dapat disusun persamaan garis regresi yaitu:

$\mathrm{Y}=-0,179+0,382 \mathrm{X} 1+0,091 \mathrm{X} 2+0,030 \mathrm{X} 3-0,459 \mathrm{X} 4$ $+0,007 \times 5+\mathrm{e}$

Hasil persamaan diatas dapat diinterpretasikan masingmasing antara lain:

1. Konstanta bernilai $-0,179$ menunjukkan bahwa bila semua variabel bebas (Profitabilitas, Likuiditas, Ukuran Perusahaan, Sales Growth dan Investment Opportunity Set) bernilai 0 maka nilai kebijakan dividen sebesar $-0,179$

2. Koefisien profitabilitas bernilai positif 0,382 yang mana bila setiap peningkatan profitabilitas sebesar 1 satuan maka kebijakan dividen akan mengalami kenaikan sebesar 0,382

3. Koefisien likuiditas bernilai positif 0,091 yang mana bila setiap peningkatan likuiditas sebesar 1 satuan maka kebijakan dividen akan mengalami kenaikan sebesar 0,091.

4. Koefisien ukuran perusahaan bernilai positif 0,030 yang mana bila setiap peningkatan ukuran perusahaan sebesar 1 satuan maka kebijakan dividen akan mengalami kenaikan sebesar 0,030.

5. Koefisiensi sales growth bernilai negatif sebesar 0,459 yang mana bila setiap peningkatan sales growth sebesar 1 satuan maka kebijakan dividen akan mengalami penurunan sebesar 0,459 .

6. Koefisiensi IOS bernilai positif 0,007 yang mana bila setiap peningkatan investment opportunity set sebesar
1 satuan maka kebijakan dividen akan mengalami peningkatan sebesar 0,007 .

Tabel 7. Uji F

\begin{tabular}{ccccc}
\hline$F_{\text {hitung }}$ & $\mathrm{F}_{\text {tabel }}$ & Sig & Std & Keterangan \\
\hline 5,659 & 2,323 & 0,000 & $<0,05$ & Model Layak \\
\hline
\end{tabular}

Sumber: Hasil Data Olahan Penelitian, 2020

Berdasarkan uji kelayakan model seperti tersaji tabel 7 memperoleh hasil $F_{\text {hitung }}>F_{\text {tabel }}(5,659>2,323)$ dan nilai sig $<0,05$ yang artinya model regresi sudah fiat atau dapat diartikan secara bersamaan semua variabel bebas (profitabilitas, likuiditas, ukuran perusahaan, sales growth dan IOS) berpengaruh terhadap variabel terikat (kebijakan dividen).

Tabel 8. Uji t

\begin{tabular}{lcccc}
\hline \multicolumn{1}{c}{ Hipotesis } & $\mathrm{t}_{\text {hitung }}$ & $\mathrm{t}_{\text {tabel }}$ & Sig & Ket \\
\hline Profitabilitas & 0,633 & 1,998 & 0,528 & H1 ditolak \\
Likuidias & 2,311 & 1,988 & 0,023 & H2 diterima \\
& & & & \\
Ukuran & 0,678 & 1,988 & 0,500 & H3 ditolak \\
$\begin{array}{l}\text { Perusahaan } \\
\text { Sales Growth }\end{array}$ & - & 1,988 & 0,008 & H4 diterima \\
& 2,718 & & & \\
IOS & 1,778 & 1,988 & 0,079 & H5 ditolak \\
\hline
\end{tabular}

Sumber: Hasil Data Olahan Penelitian, 2020

Berdasarkan tabel tersaji diatas dari hasil uji hipotesis (uji t) dapat dijelaskan sebagai berikut:

a. Dari hasil perhitungan $t_{\text {hitung }}$ dari variabel profitabilitas diperoleh 0,633 . Ternyata nilai $t_{\text {hitung }}$ lebih kecil dari nilai $t_{\text {tabel }}(0,633<1,988)$ dan nilai sig lebih besar dari tingkat signifikan $(0,528>0,050)$. Sehingga hasil ini menunjukkan profitabilitas tidak berpengaruh terhadap kebijakan dividen, maka hipotesis 1 ditolak.

b. Dari hasil perhitungan $t_{\text {hitung }}$ dari variabel likuiditas diperoleh 2,311. Ternya $t_{\text {hitung }}$ lebih besar dari $t_{\text {tabel }}$ $(2,311>1,988)$ dan nilai sig lebih kecil dari tingkat signifikan $(0,023<0,050)$. Sehingga hasil ini menunjukkan likuiditas berpengaruh terhadap kebijakan dividen, maka hipotesis 2 diterima.

c. Dari hasil perhitungan $t_{\text {hitung }}$ dari variabel ukuran perusahaan diperoleh 0,678 . Ternyata $t_{\text {hitung }}$ lebih kecil dari $t_{\text {tabel }}(0,678<1,988)$ dan nilai sig lebih besar dari tingkat signifikan $(0,500>0,050)$. Sehingga hasil ini menunjukkan ukuran perusahaan tidak berpengaruh terhadap kebijakan dividen, maka hipotesis 3 ditolak.

d. Dari hasil perhitungan $t_{\text {hitung }}$ dari variabel sales growth diperoleh $-2,718$. Ternyata $-t_{\text {hitung }}$ lebih kecil dari $-\mathrm{t}_{\text {tabel }}(-2,718<-1,988)$ dan nilai sig lebih kecil dari tingkat signifikansi $(0,008<0,050)$. Sehingga hasil ini menunjukkan sales growth berpengaruh negatif terhadap kebijakan dividen, maka hipotesis 4 diterima. 
e. Dari hasil perhitungan $t_{\text {hitung }}$ dari variabel IOS diperoleh 1,788 . Ternyata $t_{\text {hitung }}$ lebih besar dari $t_{\text {tabel }}$ $(1,788>1,988)$ dan nilai sig lebih besar dari tingkat signifikansi $(0,079>0,050)$. Sehingga hasil ini menunjukkan IOS tidak berpengaruh terhadap kebijakan dividen, maka hipotesis 5 ditolak.

Tabel 9. Uji Koefisien Determinasi

\begin{tabular}{ll}
\hline Adjusted $R$ Square & Keterangan \\
\hline 0,207 & Berpengaruh 20,7\% \\
\hline
\end{tabular}

Sumber: Hasil data olahan peneliti, 2020

Berdasarkan tabel 9 tersaji diatas menunjukkan variasi kebijakan dividen diproksikan DPR dapat dijelaskan oleh semua variable bebas pada peneliti ini sejumlah $20,7 \%$ sedangkan sisnya $79,3 \%$ dijelaskan faktor variabel diluar yang tidak diikutkan.

\section{Pembahasan}

\section{Pengaruh Profitabilitas Terhadap Kebijakan Dividen}

Berdasarkan hasil pengujian seperti tersaji pada tabel 8 menunjukkan profitabilitas tidak berpengaruh terhadap kebijakan dividen pada perusahaan LQ45 periode 2015-2019. Hasil penelitian profitabilitas yang diproksikan ROA ternyata tidak dapat mempengaruhi kebijakan dividen, jadi laba yang diperoleh bukan faktor acuan utama dalam penentuan besarnya dividen yang dibayarkan. Perusahaan mature atau matang cenderung memiliki ketersediaan lebih pada cadangan laba atau arus kas yang dapat digunakan, baik untuk kegiatan investasi maupun didistribusikan sebagai dividen, tanpa harus mengubah proporsi dividen pada pemegang saham, (Sejati et al 2020). Dengan demikian, perusahaan tidak bertumpu pada besarnya laba yang didapatkan. Hasil penelitian ini mendukung penelitian Lin et al (2018) menunjukkan profitabilitas tidak berpengaruh terhadap kebijakan dividen. Namun berbanding dengan Kurniawan \& Jin (2017), Ali et al (2018), dan Hesniati \& Hendra (2019) menyatakan profitabilitas berpengaruh atau memiliki hubungan terhadap kebijakan dividen, karena hal ini bisa disebabkan adanya perbedaan pemilihan sampel objek peneliti maupun periode tahun yang dilakukan.

\section{Pengaruh Likuiditas Terhadap Kebijakan Dividen}

Berdasarkan hasil pengujian seperti tersaji pada tabel 8 menunjukkan likuiditas berpengaruh terhadap kebijakan dividen pada perusahaan LQ45 periode 20152019. Dari hasil tersebut besar kecilnya nilai likuidtas yang diproksikan current ratio dapat mempengaruhi terhadap kebijakan dividen. Hal ini menunjukkan makin besar jumlah aktiva lancar dibanding dengan liabilitas lancar perusahaa, maka semakin besar tingkat likuiditas perusahaan tersebut serta membagikan dividen pada para pemegang saham. Semakin likuid akan membuat semakin kecil kemungkinan perusahaan akan kesulitan keuangan, termasuk membayar kewajiban lancarnya.Hal tersebut memberikan celah untuk pemegang saham jika perusahaan dalam kondisi baik dan mampu membayarkan dividen dalam jumlah tinggi. Hasil penelitian ini mendukung penelitian Mui \& Mustapha (2016), Kurniawan \& Jin (2017), dan Ahmad et al (2019) menunjukkan likuiditas berpengaruh terhadap kebijakan dividen. Namun berbanding dengan Patrick et al (2017) dan Lin et al (2018) menyatakan likuiditas tidak memiliki efek berpengaruh terhadap kebijakan dividen, karena hal ini bisa disebabkan adanya perbedaan pemilihan sampel objek peneliti maupun periode tahun yang dilakukan.

\section{Pengaruh Ukuran Perusahaan Terhadap Kebijakan Dividen}

Berdasarkan hasil pengujian seperti tersaji pada tabel 8 menunjukkan ukuran perusahaan tidak berpengaruh terhadap kebijakan dividen pada perusahaan LQ45 periode 2015-2019. Dari hasil tersebut besar kecilnya jumlah aset/ukuran perusahaan tidak memberikan efek mempengaruhi penentuan kebijakan dividen. Ketika perusahaan menunjukkan ukuran perusahaan yang meningkat rasio pembayaran dividen lebih cenderung tetap diberikan tetapi tidak menjamin jumlah dividen akan ikut meningkat. Sebaliknya ketika variabel ukuran perusahaan menurun, perusahaan tetap memberikan dividen kas kepada pemegang saham dan juga belum tentu dividen yang dibagikan jumlah yang rendah. Hasil penelitian ini sejalan dengan Hasanuh (2019) meneliti perusahaan LQ45 menunjukkan ukuran perusahaan tidak mempengaruh pada kebijakan dividen yang mana perusahaan LQ45 tergolong perusahaan bagus serta aktiva yang besar, diyakini pembagian dividen tunai merupakan hal yang biasa, sehingga saat aset tinggi ataupun rendah, perusahaan tetap akan membayarkan dividen pada pemegang saham. Oleh sebab itu, ukuran perusahaan tidak memiliki efek pengaruh pada penentuan kebijakan dividen. Hasil penelitian ini mendukung penelitian Patrick et al (2017) dan Ahmad et al (2019) menunjukkan ukuran perusahaan tidak ada hubungan pengaruh terhadap kebijakan dividen. Namun berbanding dengan Mui \& Mustapha (2016), Kurniawan \& Jin (2017) dan Hesniati \& Hendra (2019) mengemukakan ukuran perusahaan berpengauh terhadap kebijakan dividen, karena hal ini bisa disebabkan adanya perbedaan pemilihan sampel objek peneliti maupun periode tahun yang dilakukan.

\section{Pengaruh Sales Growth Terhadap Kebijakan Dividen}

Berdasarkan hasil pengujan seperti tersaji pada tabel 8 menunjukkan sales growth berpengaruh negatif terhadap kebijakan dividen pada perusahaan LQ45 periode 2015-2019. Dari hasil tersebut nilai sales growth besar maupun sebaliknya dapat mempengaruhi penentuan kebijakan dividen. Perusahaan dengan tingkat sales growth yang tinggi dan akses pasar yang baik berpengaruh terhadap keuntungan perusahaan dalam 
jumlah yang besar, namun tidak menjamin perusahaan membagikan dividen dalam jumlah tingi. Hal ini disebabkan perusahaan lebih cenderung menggunakan dananya untuk kegiatan operasi atau pertumbuhan perusahaan maka hal tersebut akan menghasilkan sasaran pembayaran dividen yang rendah dari pada mengambil pinjaman dana eksternal yang mempunyai biaya bunga yang cukup mahal. Maka dapat ditarik kesimpulan semakin tinggi pertumbuhan penjualan maka semakin rendah jumlah pembagian dividen. Hasil penelitian ini mendukung penelitian Hesniati \& Hendra (2019) menunjukkan hasil penelitian variabel sales growth berpengaruh negatif terhadap kebijakan dividen. Namun berbanding dengan Kurniawan \& Jin (2017) menyatakan sales growth tidak memiliki hubungan pengaruh terhadap kebijakan dividen, karena hal ini bisa disebabkan adanya perbedaan pemilihan sampel objek peneliti maupun periode tahun yang dilakukan.

\section{Pengaruh Investment Opportunity Set(IOS) Terhadap Kebijakan Dividen}

Berdasarkan hasil pengujan seperti tersaji pada tabel 8 menunjukkan investment opportunity set tidak berpengaruh terhadap kebijakan dividen pada perusahaan LQ45 periode 2015-2019. Dari hasil tersebut diartikan investment opportunity set bukan faktor dalam menetapkan kebijakan dividen. Investment opportunity set diproksikan market to book value of equity (MBVE). Dari nilai IOS tersebut diharapkan dapat mampu menghasilkan kesempatan investasi di masa mendatang, namun ternyata besar kecilnya nilai IOS tersebut sebagai penentuan reinvestasi perusahaan tidak dapat berpengaruh atas penentuan kebijakan dividen. Hal ini karena kemungkinan perusahaan dengan kesempatan investasi yang semakin besar maka dana lebih baik ditanamkan pada investasi yang dapat menghasilkan net present (NPV) positif. Hasil penelitian ini mendukung penelitian Fadhilaturrochmah \& Subardjo (2017) besar kecilnya IOS tidak berdampak terhadap kebijakan dividen. Namun berbanding dengan Mui \& Mustapha (2016) dan Aini \& Sawitri (2020) menyatakan variabel $I O S$ memiliki efek pengaruh terhadap kebijakan dividen, karena hal ini bisa disebabkan adanya perbedaan pemilihan sampel objek peneliti maupun periode tahun yang dilakukan.

\section{SIMPULAN}

Penelitian ini untuk mencapai tujuan peneliti dengan dilakukannya penelitian untuk mengetahui pengaruh faktor internal perusahaan terhadap kebijakan dividen. Populasi yang digunakan seluruh perusahaan LQ45 yang listed di Bursa Efek Indonesia periode 20152019. Terdapat 18 perusahaan yang memenuhi standar penelitian, sehingga diperoleh dengan total 90 observasi dari periode 2015-2019. Metode pengujian data melalui analisis regresi berganda memberikan hasil yang dapat simpulkan bahwa secara pengujian kelayakan model (uji
F) menunjukkan variabel bebas (profitabilitas, likuiditas, ukuran perusahaan, sales growth dan IOS) berpengaruh secara bersamaan terhadap variabel terikat (kebijakan dividen). Namun dalam pengujian hipotesis (uji-t) variabel profitabilitas, ukuran perusahaan, dan IOS tidak berpengaruh terhadap kebijakan dividen, sedangkan variabel likuiditas berpengaruh terhadap kebijakan dividen serta sales growth berpengaruh negatif terhadap kebijakan dividen.

\section{DAFTAR PUSTAKA}

Ahmad, N., Ansari, M. N., \& Shamsi Feroz, A. (2019). Factors Affecting Dividend Payout: Empirical Investigation From Cement Sector of Pakistan. The Journal of Economic Research \& Business Administration, 128(2).

Aini, S. N., \& Sawitri, A. P. (2020). Dampak Sales Growth , Posisi Kas, Investment Opportunity Set , Kepemilikan Institusional Terhadap Kebijakan Dividen pada Indeks Kompas 100. Majalah Ekonomi, 25(1), 36-42.

Ali, N. Y., Mohamad, Z., \& Baharuddin, N. S. (2018). The Impact of Ownership Structure on Dividend Policy : Evidence of Malaysian Listed Firms. Journal of Global Business and Social Entrepreneurship (GBSE), 4(10), 35-44.

Brigham, E. F., \& Houston, J. F. (2011). Dasar-dasar Manajemen Keuangan Edisi 11. Jakarta: Erlangga.

Fadhilaturrochmah, A., \& Subardjo, A. (2017). Pengaruh Kepemilikan Manajerial, Free Cash Flow Dan Investment Opportunity Set Terhadap DPR. Jurnal Ilmu Dan Riset Akuntansi, 6(7).

Ghozali, I. (2012). Aplikasi Analisis Multivariat dengan Program IBM SPSS 20. Semarang: Badan Penerbit Universitas Diponegoro.

Hanafi, M. M. (2004). Manajemen Keuangan. Yogyakarta: BPFE.

Harahap, S. S. (2016). Analisis Kritis atas Laporan Keuangan. Jakarta: PT Raja Grafindo Persada.

Hasanuh, N. (2019). Pengaruh Investment Opportunity Set dan Ukuran Perusahaan terhadap Deviden Kas. Jurnal SEKURITAS (Saham, Ekonomi, Keuangan Dan Investasi), 3(1), 33-44.

Hesniati, H., \& Hendra, Y. (2019). Faktor yang Mempengaruhi Rasio Pembayaran Dividen Perusahaan BEI. JESYA (Jurnal Ekonomi \& Ekonomi Syariah), 2(1).

Kasmir. (2012). Analisis Laporan Keuangan. Jakarta: PT Raja Grafindo Persada.

Kurniawan, W. A., \& Jin, T. F. (2017). Faktor-Faktor Yang Mempengaruhi Kebijakan Dividen Pada Perusahaan Non Keuangan Yang Terdaftar Di Bursa Efek Indonesia. Jurnal Bisnis Dan Akuntansi, 19(3), 191-199.

Lin, O. C., Thaker, H. M. T., Khaliq, A., \& Thaker, M. A. M. T. (2018). The Determinants of Dividend 
Payout: Evidence from the Malaysian Property Market. IQTISHADIA (Jurnal Kajian Ekonomi Dan Bisnis Islam), 11(1).

Mui, Y. T., \& Mustapha, M. (2016). Determinants of Dividend Payout Ratio: Evidence from Malaysian Public Listed Firms. Journal of Applied Environmental and Biological Sciences, 6(March), 48-54.

Nasution, D. A. D., \& Ramadhan, P. R. (2020). FaktorFaktor Yang Mempengaruhi Kebijakan Deviden Pada Perusahaan LQ 45. Jurnal Bisnis Net, 6-17.

Noefiansyah, D., \& Idayati, F. (2019). Pengaruh Profitabilitas, Firm Size, Likuiditas dan Leverage Terhadap Kebijakan Dividen. Jurnal Ilmu Dan Riset Akuntansi, 8(9), 1-19.

Noor, H. F. (2009). Investasi Pengelolaan Keuangan Bisnis dan Perkembangan Ekonomi. Jakarta: Indeks.

Patrick, D. Z., Theophilus, M. M. A., \& Mirian, M. M. (2017). Determinants of Dividend Policy of Petroleum Firms in Nigeria. IOSR Journal of Economics and Finance, 08(03), 54-62.

Putri, A. R., \& Andayani. (2017). Pengaruh Kebijakan Hutang, Profitabilitas, Likuiditas, dan Kesempatan Investasi terhadap Kebijakan Dividen. Jurnal Ilmu Dan Riset Akuntansi, 6(6), 1-15.

Ratnasari, P. S. P., \& Purnawati, N. K. (2019). Pengaruh Profitabilitas, Likuiditas, Tingkat Pertumbuhan Perusahaan Dan Leverage Terhadap Kebijakan Dividen. E-Jurnal Manajemen Universitas Udayana, 8(10), 6179-6198.

Riyanto, B. (2011). Dasar-dasar Pembelanjaan Perusahaan Edisi 4 Cetakan Ketujuh . Yogyakarta: BPFE UGM.

Rudianto. (2012). Pengantar Akuntansi Konsep \& Teknik Penyusunan Laporan Keuangan. Jakarta: Erlangga.

Sartono, A. (2010). Manajemen Keuangan: Teori dan Aplikasi Edisi 4. Yogyakarta: BPFE.

Sejati, F. R., Ponto, S., Prasetianingrum, S., Sumartono, S., \& Sumbari, N. N. (2020). Faktor-Faktor Yang Mempengaruhi Kebijakan Dividen. Berkala Akuntansi Dan Keuangan Indonesia, 5(2), 110 131.

Sudana, I. M. (2015). Manajemen Keuangan Perusahaan . Jakarta: Erlangga.

Sutrisno. (2013). Manajemen Keuangan: Teori, Konsep dan Aplikasi Cetakan ke-9. Yogyakarta: Ekonisia. 